Isti Dwi Mulya Ningsih, Luqman Hakim. (2020). Pengembangan Buku Kontekstual Mata Pelajaran Layanan Lembaga Keuangan Syariah. Jurnal Penelitian dan Pengembangan Pendidikan. Vol. 4 (2) pp. 278-288.

\title{
Pengembangan Buku Kontekstual Mata Pelajaran Layanan Lembaga Keuangan Syariah
}

\author{
Isti Dwi Mulya Ningsih"1*, Luqman Hakim² \\ 12 Pendidikan Akuntansi, Fakultas Ekonomi, Universitas Negeri Surabaya
}

\begin{abstract}
Abstrak
Penerapan K13 Revisi memberikan perubahan pada Jurusan Perbankan Syariah di SMK yakni adanya pergantian mata pelajaran Produk Syariah menjadi Layanan Lembaga Keuangan Syariah yang mana belum tersedia buku pelajaran yang memuat seluruh kompetensi dasar. Penelitian pengembangan ini ditujukan dalam mengembangkan produk berupa buku ajar kontekstual Layanan Lembaga Keuangan Syariah untuk siswa Kelas XI Semester 2 Perbankan Syariah berdasarkan standar BSNP 2014. Penelitian pengembangan ini menguji validitas kelayakan buku teks dan respon siswa pada buku teks. Validitas kelayakan diuji oleh ahli serta uji coba dilaksanakan terbatas kepada siswa Perbankan Syariah 1 SMK Negeri 1 Lamongan. Model pengembangan pada penelitian ini menerapkan model 4D yang meliputi tahap pendefinisian, desain, pengembangan, dan penyebaran. Hasil penelitian pengembangan menunjukkan validitas buku teks dalam kelayakan materi, bahasa, dan grafis didapatkan nilai dengan rata-rata 96,05\% yang digolongkan dalam kriteria interpretasi sangat layak. Penilaian hasil angket respon siswa diperoleh skor rata-rata 95,18\% dengan interpretasi sangat layak digunakan.
\end{abstract}

\begin{abstract}
The application of K13 Revision provides change to Department of Sharia Finance at Vocational School which presents the change of Sharia Product subjects to Sharia Financial Institution Services which haven't provided textbooks that contain all basic competencies. This development research is aimed at developing product consisting contextual textbooks of Islamic Financial Institution Services for Class XI students in Semester 2 of Sharia Banking based on 2014 BSNP standard. Validity by experts and trials are limited to Sharia 1 Syariah students of SMK Negeri 1 Lamongan. The development model in this study uses the 4D development model consisting of definition, design, development, and dissemination. The results of the development research show the validity of the textbook in material, language, and graphics obtain an average value of $96.05 \%$ with very decent interpretation criteria. The results of student questionnaire responses obtained an average score of $95.18 \%$ with an interpretation very feasible to use.
\end{abstract}

\section{Keywords:}

Contextual, Sharia Financial Institutions Services, Textbook

\footnotetext{
* Corresponding author.

E-mail Addresses: istidwimulya@gmail.com (Isti Dwi Mulya Ningsih)
} 


\section{PENDAHULUAN}

Kurikulum memegang peranan yang penting terhadap keberlangsungan sistem pendidikan di Indonesia. Kurikulum dijalankan dengan maksimal serta dijalankan bersama dengan komponen yang efektif, maka proses pembelajaran akan berjalan serta menghasilkan siswa dengan baik. Pada saat ini, Indonesia menerapkan Kurikulum 2013 Revisi. Kurikulum 2013 Revisi menggantikan kurikulum yang ada sebelumnya yaitu Kurikulum Tingkat Satuan Pendidikan (KTSP) dengan basis karakter dan kompetensi. Kurikulum 2013 Revisi berbasis kepribadian atau budi pekerti dan keahlian serta menyesuaikan terhadap perkembangan Ilmu Pengetahuan dan Teknologi (IPTEK) guna mempersiapkan siswa yang kreatif, produktif, inventif, dan afektif serta dapat bersaing di era globalisasi. Kurikulum 2013 Revisi menyatukan empat perihal penting pada implementasinya, yakni kekuatan pengajaran budi pekerti, literasi, High Order Thinking Skills (HOTS), dan kecakapan dalam Abad 21 yang meliputi komunikasi, kerja sama, kritis dan menemukan solusi dalam permasalahan, serta kreatif dan inovatif dalam proses pembelajaran.

Sekolah Menengah Kejuruan mengimplementasi Kurikulum 2013 Revisi dengan program keahlian sesuai jenis pekerjaan yang dibutuhkan. Menurut (Dikdasmen, 2018), struktur kurikulum SMK tahun 2018 terdapat tiga kompetensi keahlian pada program keahlian Akuntansi dan Keuangan, yakni (1) Akuntansi dan Keuangan Lembaga, (2) Perbankan dan Keuangan Mikro, dan (3) Perbankan Syariah. Implementasi Kurikulum 2013 Revisi pada program keahlian Perbankan Syariah mengakibatkan munculnya mata pelajaran yang baru, yakni Layanan Lembaga Keuangan Syariah yang menggantikan Produk Syariah.

Bahan ajar merupakan sarana belajar yang memuat materi, metode, dan evaluasi dengan desain secara teratur dan menarik siswa untuk memperoleh tujuan pembelajaran yang serasi dengan kompetensi dasar dan subkompetensi (dalam (Lestari, 2013)). Hal ini juga sejalan dengan (Kelana dan Fadly, 2019), bahan ajar yakni alat dalam pembelajaran yang dipergunakan oleh pengajar dengan runtut selama proses belajar mengajar. Fungsi bahan ajar dapat menghemat waktu pembelajaran dan dapat mengubah peran guru menjadi fasilitator (Djaramah dan Zain, 2010). Penggunaan bahan ajar dalam proses pembelajaran dapat membantu meningkatkan kemampuan pemahaman matematis siswa (Amaliah dan Sudihartinih, 2019). Dalam (Mulyasa, 2006) jenis bahan ajar meliputi bahan ajar cetak, dengar, audiovisual, serta interaktif. Bahan ajar yang kerap dipergunakan untuk pembelajaran yaitu bahan ajar cetak yang berbentuk buku ajar atau buku teks.

Buku ajar digunakan untuk instrumen atau teknik dalam pembelajaran. Buku teks digunakan oleh pendidik dan siswa semasa proses pembelajaran. Buku ajar atau buku teks merupakan sumber materi utama dalam rancangan meraih tujuan dalam kompetensi inti dan kompetensi dasar serta dapat dinyatakan layak dan digunakan dalam satuan pendidikan oleh Kementerian Pendidikan dan Kebudayaan (Permendikbud, 2016). Menurut (Prastowo, 2015) menyebutkan bahwa buku merupakan bahan ajar cetak yang banyak dipergunakan dibandingkan jenis bahan ajar lainnya karena bahan ajar cetak memiliki kelebihan yaitu dapat memudahkan pendidik dalam memberikan materi yang hendak disampaikan pada siswa, biaya yang terjangkau, pendistribusian mudah, serta menambah motivasi siswa untuk membaca. Buku memiliki empat jenis yaitu buku ajar, buku pedoman guru, buku evaluasi, serta buku referensi (Permendikbud No 2, 2008). Fungsi buku ajar menurut (Sitepu, 2012) yakni dapat mempersiapkan siswa sebelum kegiatan pembelajaran di kelas dan dapat berfungsi sebagai dasar membuat desain pembelajaran bagi guru.

Menurut (Johnson, 2011) pembelajaran kontekstual adalah metode dalam belajar yang dilandaskan pada pengetahuan dan penyelidikan bahwa siswa akan dapat memahami materi pelajaran manakala siswa memahami makna yang diperoleh, dan siswa memahami penjelasan yang berhubungan dengan pekerjaan sekolah apabila siswa dapat mempertautkan materi yang baru dengan wawasan serta pengalaman yang dilalui sebelumnya. Pendekatan pembelajaran kontektual yaitu pendekatan pembelajaran yang mengasosiasikan sekitar substansi yang sedang dipelajari dengan aktivitas nyata siswa dalam kegiatan keseharian, baik di dalam kelompok, akademik, atau bangsa yang bertujuan guna menemukan dan memahami arti dari materi pelajaran tersebut bagi aktivitasnya (Komalasari, 2010). Bahan ajar kontekstual yakni bahan ajar yang menghubungkan teori dan pelajaran dengan keseharian siswa (Sudarno, Sunarno, dan Sarwanto, 2015).

Setelah melakukan studi pendahuluan, yakni wawancara terhadap guru pengampu mata pelajaran Layanan Lembaga Keuangan Syariah di SMK Negeri 1 Lamongan pada tanggal 2 Oktober 2019, diperoleh fakta bahwa di SMK Negeri 1 Lamongan belum tersedianya buku Layanan Lembaga Keuangan Syariah yang memuat seluruh Kompetensi Dasar dan juga belum adanya pendistribusian buku dari pemerintah maupun penerbit, baik di sekolah maupun di pasaran. Buku referensi yang ada di perpustakaan sekolah, hanya ada buku referensi umum dan belum memenuhi seluruh materi ajar dalam Kompetensi Dasar. Selama ini, guru menyiapkan materi dengan mengambil informasi dari beberapa 
referensi di internet dan hasil diklat, buku umum, serta bertukar informasi dengan guru. Materi tersebut dijadikan handout oleh guru pengampu. Siswa mengalami kesulitan dalam memahami materi, karena handout yang diberikan guru memuat garis besar materi dan belum terintegrasi dengan teknologi. Siswa diberikan fasilitas wifi yang memadai untuk menunjang proses belajar mengajar.

Untuk memudahkan siswa dalam menguasai materi agar tercapai tujuan belajar mengajar, dibutuhkan buku dengan basis kontekstual. Hasil penelitian yang dilaksanakan oleh (Surdin, 2018) bahwa terdapat pengaruh positif apabila pembelajaran menggunakan basis kontekstual. Penelitian pengembangan dimaksudkan mengembangkan buku ajar yang memiliki spesifikasi kelebihan yakni dikembangkan dengan pendekatan kontekstual serta terdapat kelebihan pada bidang teknologi yakni menggunakan teknologi QR code dan fitur Teka-Teki Silang. Penggunaan teknologi dalam buku ajar dapat membuka wawasan siswa dan tersebarnya informasi dan pengetahuan (Jamun, 2018). Dalam buku ajar akan disajikan ilustrasi dan soal evaluasi yang berkaitan dengan kehidupan nyata siswa. Guru pengampu menggunakan buku umum baik dari kalangan mahasiswa maupun umum yaitu buku yang berjudul Ekonomi Kelembagaan Syariah yang disusun oleh Prof. Dr. H. Ismail Nawawi pada tahun 2009 dan buku yang berjudul Akuntansi Perbankan Syariah oleh Osmad Muthaher pada tahun 2012. Hal tersebut ternyata selaras dengan survey yang ditemukan peneliti pada sebuah toko buku, bahwa hanya terdapat buku kalangan mahasiswa dan umum salah satunya yang ditulis oleh Jeni Susyanti, sehingga fakta belum terdapatnya buku Layanan Lembaga Keuangan Syariah dengan basis kontekstual untuk Kelas XI SMK itu memang benar adanya.

Kajian empiris yaitu penelitian terdahulu yang dilakukan oleh (Suryani dan Mulyani, 2020) yang memperoleh hasil yaitu nilai-nilai wirausaha yaitu nilai kreatif, nilai kemandirian, nilai kepemimpinan, nilai-nilai bantalan risiko, dan nilai-nilai berorientasi tindakan yang dikembangkan dikategorikan sebagus dari aspek kelayakan konten, penyajian bahasa adalah lebih dari 75\%. Penelitian pengembangan ini dilaksanakan untuk menciptakan bahan ajar yang hanya memuat tiga materi pokok dan terintegrasi pada nilai-nilai kewirausahaan pada mata pelajaran ekonomi Kelas X SMA yang menjadi kekuatan penelitian. Namun pada penelitian yang dilakukan peneliti, mengembangkan dan menciptakan buku ajar yang memuat lima Kompetensi Dasar atau memuat satu semester pada Semester II Kelas XI.

Penelitian lain juga dilakukan oleh (Widodo, 2017) dengan hasil bahan ajar kimia materi elektrokimia untuk SMK Teknik Mesin sangat layak digunakan untuk buku siswa. Penelitian tersebut menggunakan model pengembangan 4D dari Thiagarajan, namun tidak melaksanakan tahap penyebaran atau disseminate. Bahan ajar kimia materi elektrokimia tersebut juga tidak terintegrasi dengan teknologi yang ada. Peneliti mengembangkan buku ajar sampai dengan tahapan penyebaran dan buku ajar memuat teknologi yaitu QR Code.

Penelitian yang dilakukan oleh (Lilis, Ruhiat, dan Djumena, 2019) yang memperoleh hasil layak digunakan dalam proses pembelajaran. Produk akhir yang dikemas dalam bentuk CD dan hanya dapat digunakan dalam PC atau laptop. Penelitian ini, menyebarluaskan produk hanya dengan mensosialissikan produk jadi kepada seluruh guru mata pelajaran di SMK Negeri 4 Pandeglang. Peneliti menyebarkan produk buku ajar kepada 3 SMK Negeri di Kabupaten Lamongan dan Kota Mojokerto.

Penelitian ini memiliki tujuan untuk menganalisis proses pengembangan buku ajar berbasis kontekstual Layanan Lembaga Keuangan Syariah Kelas XI SMK Perbankan Syariah, menganalisis kelayakan buku ajar berbasis kontekstual, serta menganalisis respon siswa Kelas XI SMK Perbankan Syariah terhadap buku ajar. Buku ajar basis kontekstual pada penelitian ini memiliki spesifikasi kelebihan yakni dikembangkan dengan pendekatan kontekstual serta terdapat kelebihan pada bidang teknologi yakni menggunakan teknologi QR code di dalamnya. Tidak hanya QR code, buku ajar yang dikembangkan juga memuat Teka Teki Silang yang dapat dijawab oleh siswa pada saat pengayaan individu, yang mana siswa SMK diharapkan untuk kreatif dan mandiri selama proses pembelajaran (Margana dan Widyantoro, 2017). Sehingga dalam pelaksanaannya, buku ajar ini dapat dikaitkan antara materi dalam pembelajaran dengan kondisi nyata keseharian siswa serta dapat menjadikan siswa mermbangun dan mencetuskan hubungan antara pemahaman dengan realita.

\section{METODE PENELITIAN}

Jenis penelitian yang digunakan yaitu penelitian dan pengembangan (Research\&Development). Menurut (Sugiyono, 2014) penelitian dan pengembangan merupakan jenis riset yang dipergunakan dalam menciptakan produk serta mengukur tingkat kelayakan produk. Penelitian dan pengembangan ini, peneliti menggunakan model pengembangan 4D yang dikembangkan oleh S. Thiagarajan, Dorothy S. Semmel, dan Melvyn I. Semmel pada Tahun 1974. Model pengembangan 4D terdiri dari 4 tahap utama, yakni Define (tahap pendefinisian), Design (tahap desain), Develop (tahap pengembangan), dan Disseminate (tahap penyebaran). Berikut prosedur penelitian model pengembangan 4D meliputi, analisis 
ujung depan, analisa siswa, analisis pekerjaan, analisa konsepsi, perumusan tujuan pembelajaran pada tahapan pendefinisian. Pada tahapan desain, dilakukan pemilihan bentuk, rencana awal menciptakan draf produk 1. Telaah ahli materi, telaah ahli bahasa, telaah ahli grafis, analisis data dan revisi menciptakan draf produk 2, validasi ahli, uji coba pengembangan, analisa data uji coba di tahap pengembangan. Dan pada tahap penyebaran dilakukan pengemasan, penyebaran dan pengadopsian.

Subjek pada penelitian melibatkan dua ahli materi, satu ahli bahasa, satu ahli grafis, dan siswa. Ahli materi terdiri dari satu orang guru pengampu mata pelajaran Layanan Lembaga Keuangan Syariah dan satu orang dosen pengampu mata kuliah perbankan syariah di Universitas Negeri Surabaya. Ahli bahasa yaitu satu orang dosen dari Jurusan Pendidikan Bahasa dan Sastra Indonesia, Fakultas Bahasa, Universitas Negeri Surabaya. Ahli grafis yakni satu orang dosen dari Jurusan Kurikulum dan Teknologi Pendidikan, Universitas Negeri Surabaya. Siswa dalam maksud adalah siswa Kelas XI Perbankan Syariah 1 SMK Negeri 1 Lamongan dengan jumlah 20 siswa.

Penelitian ini melaksanakan uji coba secara terbatas kepada 20 siswa Kelas XI Perbankan Syariah 1 SMK Negeri 1 Lamongan. Pemilihan XI Perbankan Syariah 1 dilakukan karena hasil penilaian pada 3 kompetensi dasar pada semester 1 yang telah dilaksanakan oleh guru pengampu mata pelajaran, diperoleh bahwa XI Perbankan Syariah 1 memiliki karakteristik siswa yang aktif dan hasil pembelajaran yang lebih baik daripada XI Perbankan Syariah 2. Pada tahap disseminate dilakukan secara terbatas yakni disebarkan kepada guru pengampu mata pelajaran Layanan Lembaga Keuangan Syariah Kelas XI di SMK Negeri Kabupaten Lamongan dan Kota Mojokerto, yakni di SMK Negeri 1 Lamongan, SMK Negeri 1 Sambeng Lamongan, serta SMK Negeri 2 Kota Mojokerto.

Data yang diterima pada penelitian dan pengembangan ini berupa data kualitatif serta data kuantitatif. Data kualitatif dalam penelitian pengembangan didapatkan dari telaah ahli materi, bahasa, serta grafis. Data kualitatif ini berbentuk komentar atau masukan yang diberikan oleh ahli pada lembar telaah ahli terhadap buku ajar. Data kuantitatif dalam penelitian dan pengembangan didapatkan dari hasil validasi dari ahli materi, bahasa, serta grafis yang berupa lembar penilaian produk pengembangan. Lembar validasi dari ahli disajikan dengan menggunakan skala likert. Data kuantitatif serta didapatkan dari analisis dari angket respon siswa dengan penyajian menggunakan skala guttman.

Lembar telaah dan validasi ahli akan ditelaah oleh empat validator, yakni dua orang ahli materi, satu orang ahli bahasa, serta satu orang ahli grafis. Hasil validasi dari para ahli akan dianalisis dengan skor skala likert sebagai berikut,

Tabel 1. Tolok Ukur Skor Validasi Ahli dengan Skala Likert

\begin{tabular}{lcc}
\hline & Kriteria & Skor \\
\hline Sangat layak & 5 \\
Layak & 4 \\
Cukup layak & 3 \\
Tidak layak & 2 \\
Sangat tidak layak & 1 \\
\hline
\end{tabular}

Sumber: (Riduwan, 2016)

Hasil validasi dari ahli akan dihitung dengan cara:

$$
\text { Persentase }(\%)=\frac{\text { Jumlah skor }}{\text { Jumlah skor maksimal }} \times 100 \%
$$

Berdasarkan penghitungan hasil validasi ahli di atas akan didapatkan kelayakan buku ajar yang dikembangkan, kriteria interpretasi dari hasil validasi ahli dianalisis sebagai berikut,

Tabel 2. Interpretasi Skor Validasi Ahli dengan Skala Likert

\begin{tabular}{cc}
\hline Persentase & Kriteria Interpretasi \\
\hline $0 \%-20 \%$ & Sangat tidak layak \\
$20 \%-40 \%$ & Tidak layak \\
$40 \%-60 \%$ & Cukup layak \\
$60 \%-80 \%$ & Layak \\
$80 \%-100 \%$ & Sangat layak \\
\hline
\end{tabular}


Berdasar tabel di atas, buku ajar dapat dinyatakan layak atau sangat layak apabila persentase rerata dari seluruh komponen penilaian validasi ahli memperoleh $>61 \%$. berikut,

Angket respon siswa dianalisis dengan menggunakan skala guttman dengan kriteria sebagai

Tabel 3. Kriteria Skor Angket Respon dengan Skala Guttman

\begin{tabular}{cc}
\hline Kriteria & Skor \\
\hline Ya & 1 \\
Tidak & 0 \\
\hline & Sumber: (Riduwan, 2016)
\end{tabular}

Dari angket respon akan dihitung persentasenya dan dianalisis dengan cara:

$$
\text { Persentase }(\%)=\frac{\text { Jumlah skor }}{\text { Jumlah skor maksimal }} \times 100 \%
$$

Berdasarkan penghitungan hasil analisis tersebut, akan didapatkan kelayakan pada buku ajar yang dikembangkan dari hasil angket respon siswa dengan analisis kriteria interpretasi berikut,

Tabel 4. Interpretasi Skor Angket Respon dengan Skala Guttman

\begin{tabular}{cc}
\hline Persentase & Kriteria Interpretasi \\
\hline $0 \%-20 \%$ & Sangat tidak layak \\
$21 \%-40 \%$ & Tidak layak \\
$41 \%-60 \%$ & Cukup layak \\
$61 \%-80 \%$ & Layak \\
$81 \%-100 \%$ & Sangat layak \\
\hline
\end{tabular}

Sumber : (Riduwan, 2016)

Dari Tabel tersebut, apabila seluruh komponen penilaian dalam angket respon siswa memperoleh rerata persentase $>61 \%$ maka buku ajar yang dikembangkan akan memperoleh kriteria interpretasi layak atau sangat layak.

\section{ANALISIS DAN PEMBAHASAN}

\section{A. Proses Pengembangan Buku Ajar}

Tahap pertama dalam proses pengembangan buku ajar berbasis kontekstual adalah melaksanakan tahap pendefinisian atau define. Dalam model 4D yang dikembangkan oleh Thiagarajan Tahun 1974, pada tahap pendefinisian ditujukan untuk menganalisis persoalan yang terjadi pada pembelajaran di sekolah dan menganalisis 5 kegiatan yakni analisis ujung depan, analisis siswa, analisis tugas, analisis konsep, dan perumusan tujuan pembelajaran. Pada analisis ujung depan, dilakukan analisis permasalahan yang terjadi dalam mata pelajaran Layanan Lembaga Keuangan Syariah yaitu belum tersedianya buku ajar yang memuat seluruh Kompetensi Dasar dan juga belum tersedianya buku dari pemerintah maupun penerbit. Hal ini juga sejalan dengan penelitian yang dilakukan oleh (Amalia dan Hakim, 2019), bahwa belum tersedianya buku ajar yang memuat kompetensi dasar secara utuh.

Setelah proses analisis ujung depan, dilakukan analisis untuk siswa. Kemampuan siswa Kelas XI Perbankan Syariah dalam berinteraksi dan bekerja sama sudah baik. Motivasi siswa dalam proses pembelajaran akan meningkat apabila tersedianya buku ajar yang dapat meunjang proses pembelajaran. Latar belakang siswa SMKN 1 Lamongan memiliki latar belakang yang hampir sama, yakni lingkungan yang masih berdekatan serta memiliki usia dengan rentang 16-17 tahun, di mana berdasarkan tahap perkembangan kogitif piaget menurut (Nursalim, 2016) usia di atas 11 tahun sampai dewasa dalam tahapan operasional formal di mana seseorang mampu menganalisis dan memecahkan masalah dari permasalahan yang ada. Berdasarkan hasil penilaian yang dilakukan guru pengampu terhadap nilai akademik siswa didapati bahwa rata-rata nilai pengetahuan siswa berada di atas nilai KKM.

Analisis tugas bertujuan untuk merancang materi dan submateri yang akan dijelaskan serta menyusun rangkaian instruksi yang akan dilakukan siswa dalam kegiatan proses belajar mengajar sehubungan dengan pendekatan saintifik 5M yaitu mengamati, menanya, mengumpulkan informasi, menalar, serta mengomunikasikan dalam mencapai kriteria ketuntasan minimal mata pelajaran. Dalam 
buku ajar yang dikembangkan, siswa diberikan tugas untuk membaca seluruh materi yang disajikan dalam $5 \mathrm{M}$ yang ada dalam buku ajar yang serasi dengan pendekatan saintifik yaitu $5 \mathrm{M}$, lalu mengerjakan soal evaluasi yang tersedia dalam setiap bab yang terdiri dari 5 soal uraian serta soal Teka Teki Silang bagi setiap individu.

Analisis selanjutnya adalah analisis konsep yang dimaksudkan untuk menghasilkan konsep yang berisi materi pokok yang disajikan ke dalam buku ajar dan disusun secara sistematis berdasarkan kompetensi dasar yang ada di Kurikulum 2013 Revisi. Materi pokok pada buku ajar meliputi, sistem bagi hasil dan bonus produk penghimpunan bank syariah, sistem bagi hasil dan margin produk pembiayaan dana bank syariah, surat berharga pasar uang, sertifikat wadiah Bank Indonesia, dan valuta asing, Kartu ATM, Kartu Kredit, dan travelling cheque, serta safe deposit box. Langkah selanjutnya adalah perumusan tujuan belajar yang akan diselaraskan dengan kompetensi dasar yang ada pada silabus mata pelajaran Lembaga Keuangan Syariah Kelas XI semester 2 Kurikulum 2013 Revisi. Perumusan tujuan belajar ini dijadikan syarat untuk perancangan materi, kegiatan pembelajaran, serta soal evaluasi dalam buku ajar yang dikembangkan.

Tahap selanjutnya setelah tahap pendefinisian yaitu melakukan tahap perancangan (design). Menurut penelitian (Rahim dan Wahyuni, 2019), tahap perancangan ditujukan untuk merencanakan dan mempersiapkan desain awal dalam buku ajar sehingga diperoleh prototype dengan tujuan pembelajaran khusus. Tahap perancangan ini didasarkan pada Standar BSNP tahun 2014 mengenai instrumen penilaian buku teks pelajaran dan disesuaikan dengan peneliti. Format awal buku ajar meliputi bagian pendahuluan, bagian isi, dan bagian penutup. Dalam bagian awal atau pendahuluan buku ajar berisi sampul depan, halaman judul, kata pengantar, petunjuk penggunaan, daftar isi, kompetensi inti dan kompetensi dasar, serta tujuan akhir pembelajaran. Pada bagian isi berisi kompetensi dasar, tujuan pembelajaran yang hendak dicapai, kata motivasi, peta konsep, materi, fitur newsyariah, rangkuman materi, soal evaluasi, dan fitur teka-teki silang. Bagian akhir atau penutup berisi daftar pustaka, profil penulis dan sampul belakang. Buku ajar yang dirancang dengan desain awal akan direalisasikan menjadi desain awal buku ajar atau disebut draf buku I. Buku ajar ini dicetak pada kertas ukuran A4 80gram dengan bagian sampul dicetak softcover. Bagian isi buku dicetak hitam putih, hanya sampul yang dicetak berwarna. Buku ajar ini didominasi dengan warna hijau karena melambangkan syariah keislaman.

Tahapan selanjutnya yakni pengembangan (develop). Penelitian yang dilakukan oleh (Anisa dan Rohayati, 2019), dilakukan kegiatan menelaah oleh ahli dan dilakukan revisi sesuai saran ahli. Peneliti merealisasikan draf produk I yang selanjutnya akan ditelaah oleh ahli, yang mana para ahli akan memberikan saran atau masukan terhadap buku ajar. Buku ajar yang telah ditelaah para ahli akan direvisi oleh peneliti sehingga menjadi draf buku II dan selanjutnya dinilai validitas atau kelayakannya oleh para ahli. Setelah dilaksanakan validitas, peneliti akan menganalisis hasil yang telah diperoleh dari para ahli untuk diinterpretasikan sesuai dengan hasil persentase. Uji coba dilaksanakan pada 20 peserta didik Perbankan Syariah 1 SMK Negeri 1 Lamongan. Uji coba dilaksanakan melalui online yaitu buku ajar disebarkan dengan bentuk soft file dan menggunakan google form. Hasil uji coba akan dianalisis dan diinterpretasikan sesuai dengan persentase.

Tahap terakhir yakni penyebaran (disseminate). Berbeda halnya dengan penelitian yang dilakukan (Sumaeny dan Susanti, 2018) yakni tidak melaksanakan tahapan penyebaran. Pada teori yang dikembangkan oleh Thiagarajan pada tahun 1974, penyebaran dilakukan dengan tahapan pengemasan dan penyebaran. Dalam tahap pengemasan, peneliti bekerjasama dengan salah satu penerbit di Surabaya dalam hal percetakan. Tahap penyebaran dilakukan secara terbatas kepada guru pengampu mata pelajaran Layanan Lembaga Keuangan Syariah di sekolah negeri Kabupaten Lamongan dan Kota Mojokerto, yakni pada SMK Negeri 1 Lamongan, SMK Negeri 1 Sambeng, dan SMK Negeri 2 Kota Mojokerto. Respon yang diterima oleh peneliti dari guru pengampu mata pelajaran sangat positif. Buku yang diberikan peneliti sangat bermanfaat dalam menunjang proses pembelajaran, karena belum adanya pendistribusian buku dari pemerintah dan penerbit. Penelitian yang dilakukan oleh (Fajri dan Taufiqurrahman, 2017), juga melaksanakan pendistribusian yang dilakukan secara terbatas kepada guru dan peserta didik.

\section{B. Kelayakan Buku Ajar}

Kelayakan buku ajar berbasis kontekstual pada penelitian pengembangan ini didapatkan dari perhitungan hasil penilaian validasi yang dilaksanakan validator ahli materi, bahasa, serta grafis. Hasil perhitungan validasi diperoleh dari angket yang menggunakan skala likert sebagai penilaian disertai dengan kriteria penilaian. Buku ajar dinyatakan layak apabila memperoleh persentase $>61 \%$. 
Tabel 5. Hasill Validasi Ahli Materi

\begin{tabular}{clc}
\hline No. & \multicolumn{1}{c}{ Aspek } & Persentase \\
\hline 1. & Dimensi Pengetahuan & $97 \%$ \\
2. & Dimensi Keterampilan & $94 \%$ \\
3. & Teknik Penyajian & $92 \%$ \\
4. & Pendukung Penyajian Materi & $98 \%$ \\
5. & Penyajian Pembelajaran & $88 \%$ \\
6. & Kelengkapan Penyajian & $100 \%$ \\
\hline & Rata-Rata Persentase Penilaian & $\mathbf{9 4 , 8 5 \%}$ \\
& Kategori & Sangat Layak \\
\hline
\end{tabular}

Sumber: diolah peneliti (2020)

Pada tabel di atas, hasil perolehan validasi ahli materi sebesar 94,85\%. Dalam buku ajar ini, pada komponen kelayakan isi terdapat aspek kedalaman materi yang cukup, akurasi fakta dengan yang sesuai di kehidupan sehari-hari, dan karakteristik kegiatan 5M. Pada komponen kelayakan juga terdapat ketersediaan contoh soal latihan dalam setiap bab dan kelengkapan bagian pendahuluan. Sehingga berdasarkan hasil analisis validasi ahli materi tersebut, jika diinterpretasikan berdasarkan skala likert, buku ajar yang dikembangkan mendapatkan kelayakan dengan interpretasi kategori sangat layak dipergunakan dalam proses belajar mengajar. Buku ajar ini dikembangkan dengan terintegrasi teknologi terkini berupa $Q R$ Code. Berbeda hal nya dengan penelitian yang dilaksanakan oleh (Pasaribu dan Saparini, 2017) yaitu belum tersedianya fitur yang terintegrasi dengan teknologi. Buku ajar juga dilengkapi dengan fitur syariah.id, newsyariah, dan Teka Teki Silang yang dapat membuat siswa menambah informasi. Hal ini selaras dengan penelitian yang dilaksanakan (Meidy, Patmanthara, dan Arifin, 2018) bahwa bahan ajar cetak yang dikembangkan memperoleh skor validasi materi sebesar 94,01\% dengan interpretasi sangat valid. Penelitian lain juga dilakukan oleh (Astiti, 2019) memperoleh validasi ahli materi dengan nilai 86,67 dengan kategori sangat baik.

Tabel 6. Hasil Validasi Ahli Bahasa

\begin{tabular}{clc}
\hline No. & \multicolumn{1}{c}{ Aspek } & Persentase \\
\hline 1. & Kesesuaian dengan Perkembangan Siswa & $100 \%$ \\
2. & Keterbacaan & $100 \%$ \\
3. & Kemampuan Memberikan Motivasi & $100 \%$ \\
4. & Kelugasan & $100 \%$ \\
5. & Koherensi dan Keruntutan Alur Pemikiran & $100 \%$ \\
6. & Kesesuaian dengan Kaidah Bahasa Indonesia & $80 \%$ \\
7. & Penggunaan Istilah dan Simbol & $100 \%$ \\
\hline & $\quad$ Rata-Rata Persentase Penilaian & $\mathbf{9 7 , 1 4 \%}$ \\
& \multicolumn{2}{c}{ Kategori }
\end{tabular}

Sumber: diolah peneliti (2020)

Pada komponen kelayakan bahasa, memperoleh nilai validasi dengan skor 97,14\% dengan kriteria interpretasi sangat layak. Skor tersebut diperoleh karena dalam buku ajar memuat kesesuaian bahasa dengan tingkat perkembangan kemampuan siswa. Terdapat kata motivasi yang memberikan kemampuan motivasi bagi siswa. Kekonsistenan penggunaan istilah dan lambang juga menjadikan siswa memahami buku ajar. Hasil ini selaras dengan penelitian yang dilakukan (Suratno, Narulita, dan Luthfia, 2018) bahwa pada aspek bahasa memperoleh rerata $77,68 \%$ dengan kategori valid.

Tabel 7. Hasill Validasi Ahli Grafis

\begin{tabular}{clc}
\hline No. & \multicolumn{1}{c}{ Aspek } & Persentase \\
\hline 1. & Ukuran Buku & $100 \%$ \\
2. & Desain Kulit Buku & $94 \%$ \\
3. & Desain Isi Buku & $95 \%$ \\
4. & Ilustrasi Isi Buku & $95,6 \%$ \\
\hline \multicolumn{2}{c}{ Rata-Rata Persentase Penilaian } \\
\multicolumn{2}{c}{ Kategori } & $\mathbf{9 6 , 1 5 \%}$ \\
\hline & & Sangat Layak \\
\hline
\end{tabular}


Dalam tabel ditunjukkan bahwa pada kelayakan grafis, diperoleh skor validasi dengan nilai 96,15\% dengan interpretasi sangat layak. Hal ini dikarenakan ilustrasi kulit buku mampu mempresentasikan gambaran mengenai materi ajar. Ilustrasi yang harmonis dan teratur dapat memberikan kemudahan siswa dalam memahami buku ajar. Unsur tata letak dari awal hingga akhir buku ditampilkan secara utuh dan sesuai dengan materi dalam buku ajar. Sejalan dengan penelitian (Hidayah dan Pryscylio, 2019) bahwa bahan ajar yang dikembangkan memperoleh rerata kelayakan konstruk sebesar 3.25 dengan kategori layak. Penelitian yang dilakukan oleh (Swidiarta, Suardana, dan Sastrawidana, 2019) juga memperoleh nilai 4,28 dengan kategori sangat baik.

Tabel 8. Rata-Rata Hasil Validasi Ahli

\begin{tabular}{|c|c|c|}
\hline No. & Aspek & Persentase \\
\hline 1. & Materi & $94,85 \%$ \\
\hline 2. & Bahasa & $97,14 \%$ \\
\hline 3. & Grafis & $96,15 \%$ \\
\hline & $\begin{array}{c}\text { Rata-Rata Persentase Penilaian } \\
\text { Kategori }\end{array}$ & $\begin{array}{c}96,05 \% \\
\text { Sangat Layak } \\
\end{array}$ \\
\hline
\end{tabular}

Berdasar penghitungan rerata penilaian validasi oleh validator yang meliputi ahli materi, bahasa, dan grafis didapatkan rerata persentase validitas sebesar 96,05\% dengan interpretasi sangat layak. Oleh karena itu, buku ajar yang dikembangkan ini sangat layak dan bisa dipergunakan dalam menunjang proses belajar mengajar. Hasil tersebut selaras dengan penelitian yang dilakukan (Nurfita, 2018) bahwa buku ajar yang dikembangkan dengan basis kontekstual memperoleh persentase validitas sebesar 85,55\% dengan interpretasi sangat layak. Hasil ini juga sejalan pada penelitian pengembangan yang dilaksanakan (Fatihasari 2019) bahwa buku ajar layanan lembaga keuangan syariah yang dikembangkan memperoleh persentase validitas $85,65 \%$ dengan kategori sangat layak. Penelitian oleh (Fuada, Nainunis, dan Aditya, 2017) juga memperoleh skor 90\% yang berarti media pembelajaran yang dikembangkan dalam kategori sangat valid dan layak digunakan.

\section{Respon Siswa terhadap Buku Ajar}

Uji coba dilakukan terbatas guna mendapatkan respon siswa terhadap buku ajar. Respon siswa dilaksanakan dengan uji coba secara terbatas kepada 20 siswa Kelas XI Perbankan Syariah 1 SMKN 1 Lamongan. Uji coba terbatas dilaksanakan dengan sistem online karena terdapat keterbatasan dan disebarkan pada Hari Senin, 20 April 2020. Peneliti menyebarkan buku serta google form yang dapat diisi oleh siswa. Siswa dimohon mengisi angket respon dengan memberikan klik pada jawaban Ya apabila sesuai dengan pernyataan, dan jawaban Tidak apabila tidak sesuai dengan pernyataan.

Tabel 9. Angket Respon Siswa

\begin{tabular}{clc}
\hline No. & \multicolumn{1}{c}{ Aspek } & Persentase \\
\hline 1. & Isi & $97 \%$ \\
2. & Penyajian & $97 \%$ \\
3. & Bahasa & $98 \%$ \\
4. & Grafis & $91,7 \%$ \\
5. & Kesesuaian dengan Scentific Approach & $92,2 \%$ \\
\hline \multicolumn{2}{c}{ Rata-Rata Persentase Penilaian } \\
& Kategori & $\mathbf{9 5 , 1 8 \%}$ \\
& & Sangat Layak \\
\hline
\end{tabular}

Sumber: diolah peneliti (2020)

Berdasarkan tabel di atas, lembar angket respon siswa ditinjau dari komponen isi memperoleh skor sebesar 97\%. Hal ini mengindikasikan bahwa materi yang disajikan sesuai dengan mata pelajaran Layanan Lembaga Keuangan Syariah dan mudah dipahami. Dalam komponen penyajian, diperoleh skor sebesar 97\%. Hal ini menandakan penyajian isi buku ajar mudah dipahami siswa, baik dari petunjuk penggunaan, peta konsep, ilustrasi, hingga fitur yang disediakan. Komponen bahasa memperoleh persentase sebesar 98\% yang berarti bahasa dalam buku ajar berbasis kontekstual sudah sesuai dengan tingkatan usia siswa. Komponen kegrafikan memperoleh persentase sebesar 91,7\% yang mengindikasikan bahwa desain tampilan dan kombinasi warna buku ajar menarik. Kesesuaian buku ajar 
dengan scientific approach memperoleh skor sebesar 92,2\% yang berarti siswa memahami materi dengan pendekatan saintifik.

Berdasarkan penghitungan hasil penghitungan angket respon siswa tersebut, rerata persentase respon siswa sebesar 95,18\% dengan interpretasi sangat layak. Rerata persentase respon siswa tersebut dapat diasumsikan bahwa buku ajar berpotensi menjadi buku yang efektif apabila dipergunakan dalam situasi belajar (Mohammadi dan Abdi, 2014). Penelitian lain yang dilaksanakan oleh (Oktavianie, Irwandi, dan Murniati, 2018) bahwa rata-rata angket pada siswa memperoleh kategori layak dengan predikat sangat baik. Hal ini juga selaras dengan penelitian yang dilaksanakan oleh (Suwarni, 2015) bahwa adanya perbedaan hasil belajar siswa apabila menggunakan buku ajar dengan tanpa menggunakan buku ajar. Dapat disimpulkan bahwa, buku ajar berbasis kontekstual sangat layak untuk siswa dan dapat diimplementasikan oleh siswa dalam pembelajaran maupun sumber rujukan.

\section{KESIMPULAN}

Proses pengembangan buku ajar berbasis kontekstual Layanan Lembaga Keuangan Syariah Kelas XI SMK Perbankan Syariah menggunakan model pengembangan 4D. Kelayakan buku ajar berbasis kontekstual yang dikembangkan didapatkan dari penghitungan hasil analisis validasi dari validator ahli materi, bahasa, serta grafis. Berdasarkan hasil analisis buku ajar dari ke empat validator ahli memperoleh kategori interpretasi sangat layak digunakan buku ajar dalam belajar mengajar. Respon siswa Kelas XI SMK Perbankan Syariah 1 terhadap pengembangan buku ajar kontekstual Layanan Lembaga Keuangan Syariah memperoleh hasil respon dengan kriteria interpretasi sangat memahami dan dapat digunakan sebagai sumber rujukan pada proses pembelajaran.

\section{DAFTAR PUSTAKA}

Amalia, Inna Alfi, dan Luqman Hakim. 2019. Pengembangan Buku Ajar Layanan Lembaga Keuangan Syariah Berbasis Saintifik pada Siswa SMK Kelas XI Semester II Kompetensi Keahlian Perbankan Syariah. Pendidikan Akuntansi 07: 167.

Amaliah, Ikhlasul, dan Eyus Sudihartinih. 2019. Pengembangan Bahan Ajar Konsep Pecahan Berbantuan Multimedia Untuk Meningkatkan Kemampuan Pemahaman Matematis Siswa di Sekolah Inklusi. Pendidikan 04: 9.

Anisa, Cindy Avrillia, dan Suci Rohayati. 2019. Pengembangan Bahan Ajar Perbankan Dasar Berbasis Kontekstual Pada Materi Kredit Perbankan Kelas X Akuntansi di SMK Negeri Mojoagung. Pendidikan Akuntansi Unesa 7 Nomor 01: 34.

Astiti, Kadek Ayu. 2019. Pengembangan Bahan Ajar Fisika SMA Berbasis Kontekstual Pada Materi Suhu dan Kalor. Pembelajaran Sains 3: 31.

Dikdasmen. 2018. Struktur Kurikulum Sekolah Menengah Kejuruan (SMK)/MAK. http://psmk.kemdikbud.go.id/konten/3824/struktur-kurikulum-smk-perdirjen-dikdasmen-no07dd5kk2018 (Oktober 5, 2019).

Djaramah, Syaiful Bahri, dan Aswan Zain. 2010. Strategi Belajar Mengajar. Jakarta: PT. Rineka Cipta.

Fajri, Khaerul, dan Taufiqurrahman. 2017. Pengembangan Buku Ajar Menggunakan Model 4D Dalam Peningkatan Keberhasilan Pembelajaran Pendidikan Agama Islam. Pendidikan Islam Indonesia 2: 11.

Fatihasari, Kemala Agustina. 2019. Pengembangan Buku Ajar Layanan Lembaga Keuangan Syariah Berbasis Scientific Approach dengan Integrasi Teknologi QR Code. Jurnal Pendidikan Ekonomi, Manajemen dan Keuangan 3: 125.

Fuada, Syifaul, Nainunis, dan Aditya. 2017. Pengembangan Buku Ajar IPS-Sejarah Digital SMP. Teknik Informatika 10: 43.

Hidayah, Dwi Nurul, dan Ghery Pryscylio. 2019. Pengembangan Bahan Ajar Mandiri Pokok Bahasan Suhu dan Kalor Menggunakan Software Camtasia. Teaching and Learning Physics 4 1: 67. 
Jamun, Yohannes Marryono. 2018. Dampak Teknologi Terhadap Pendidikan. Pendidikan dan Kebudayaan Missio 10: 52.

Johnson, Elane B. 2011. Contextual Teaching and Learning Menjadikan Kegiatan Belajar Mengajar Mengasyikkan dan Bermakna. Bandung: Kaifa Learning.

Kelana, Jajang Bayu, dan Pratama Fadly. 2019. Bahan Ajar IPA Berbasis Literasi Sains. Bandung: LEKKAS.

Komalasari, Kokom. 2010. Pembelajaran Kontekstual Konsep dan Aplikasi. Bandung: Refika Aditama.

Lestari, Ika. 2013. Pengembangan Bahan Ajar Berbasis Kompetensi. Padang: Akademia Permata.

Lilis, Yayar Ruhiat, dan Irwan Djumena. 2019. Pengembangan Bahan Ajar Digital Pada Mata Pelajaran Dasar Listrik dan Elektronika Kelas X. Teknologi Pendidikan dan Pembelajaran 6: 156.

Margana, M, dan A Widyantoro. 2017. Developing English Textbooks Oriented to Higher Order Thinking Skills for Students of Vocational High Schools in Yogyakarta. Journal of Language Teaching and Research 8(1): 26.

Meidy, Ria Devita, Syaad Patmanthara, dan Zainal Arifin. 2018. Pengembangan Buku Ajar Cetak Dengan Model Discovery Learning Untuk Mata Pelajaran Komputer dan Jaringan Dasar Kelas X Jurusan TKJ SMK Muhammadiyah 1 Kepanjen. Pendidikan 3: 130.

Mohammadi, M., dan H Abdi. 2014. Textbook Evaluation: A Case Study. Procedia - Social and Behavioral Sciences 98: 1148.

Mulyasa. 2006. Menjadi Guru Profesional Menciptakan Pembelajaran Kreatif dan Menyenangkan. Bandung: PT Remaja Rosdakarya.

Nurfita, Reny. 2018. Pengembangan Bahan Ajar Akuntansi Keuangan Berbasis Kontekstual Pada Materi Rekonsiliasi Bank Kelas XI Akuntansi SMK Negeri di Surabaya. Jurnal Pendidikan Akuntansi 6: 308.

Nursalim, Mochamad. 2016. Psikologi Pendidikan. 5 ed. Surabaya: Unesa University Press.

Oktavianie, Maried Ayuningtyas, Dedi Irwandi, dan Dewi Murniati. 2018. Pengembangan Buku Pengayaan Kimia Berbasis Kontekstual Pada Konsep Elektrokimia. Tadris Kimiya 3: 28.

Pasaribu, Abidin, dan Saparini. 2017. Pengembangan Bahan Ajar Berbasis Kontekstual Untuk Meremidiasi Miskonsepsi pada Materi Gaya dan Hukum Newton Tentang Gerak. Inovasi dan Pembelajaran Fisika 4: 41-42.

Permendikbud. 2016. Nomor 8 Tahun 2016. In Buku yang Digunakan oleh Satuan Pendidikan, Indonesia, 2.

Permendikbud No 2. 2008. Buku Ajar. Jakarta: Menteri Pendidikan, 2.

Prastowo, Andi. 2015. Panduan Kreatif Membuat Bahan Ajar Inovatif. Jogjakarta: Diva Press.

Rahim, Rani, dan Dewi Wahyuni. 2019. Pengembangan Bahan Ajar Matematika Berbasis Pendekatan Kontekstual pada Siswa SMK Negeri 5 Medan. MathEducation Nusantara 2: 21.

Sitepu, B.P. 2012. Penulisan Buku Teks Pelajaran. Bandung: PT Remaja Rosdakarya.

Sudarno, Sunarno, dan W Sarwanto. 2015. Pengembangan Modul IPA Terpadu Berbasis Kontekstual dengan Tema Pembuatan Tahu Kelas VII SMP Negeri 2 Jatiyoso. Inkuiri 4 (3): 104-11.

Sugiyono. 2014. Metode Penelitian Pendidikan Pendekatan Kuantitatif, Kualitatif, dan R\&D. Bandung: Alfabeta. 
Sumaeny, Rossa Novia, dan Susanti. 2018. Pengembangan Bahan Ajar Akuntansi Perbankan Berbasis Kontekstual Sebagai Pendukung Implementasi Kurikulum 2013 Pada Materi Komitmen Dan Kontijensi Kelas XI Perbankan di SMK Negeri 10 Surabaya. Pendidikan Akuntansi Unesa 6: 199.

Suratno, Erlia Narulita, dan Syariffatul Luthfia. 2018. Pengembangan Buku Siswa Berbasis Kontekstual Bermuatan Nilai-Nilai Agama Islam pada Materi Bioteknologi Kelas XII SMA/MA." Edukasi 1: 45.

Surdin. 2018. The Effect of Contextual Teahing and Learning (CTL) Models on Learning Outcomes of Social Sciences of the Material of Forms The Face of The Earth on Clas VII of Junior High School. International Journal of Education and Research 6: 59.

Suryani, Dewi, dan Endang Mulyani. 2020. Development of Integrated Economic Learning Materials Entrepreneurship Values for High School. Pendidikan Ekonomi \& Bisnis 1: 66.

Suwarni, Erna. 2015. Pengembangan Buku Ajar Berbasis Lokal Materi Keanekaragaman Laba-Laba di Kota Metro Sebagai Sumber Belajar Alternatif Biologi Untuk Siswa SMA Kelas X. Pendidikan Biologi 6: 86.

Swidiarta, Suardana, dan Sastrawidana. 2019. Pengembangan Buku Ajar Kimia SMA Kelas X Berbasis Argumen Toulmin. Matematika, Sains, dan Pembelajarannya 13: 139.

Widodo, Wiwik. 2017. Pengembangan Bahan Ajar Elektronikimia Terintegrasi Berbasis Kontekstual Untuk SMK Teknik Mesin. Pena Sains 4: 80. 